\title{
Airway Smooth Muscle Changes in the Nitrofen-Induced Congenital Diaphragmatic Hernia Rat Model
}

\author{
JAQUES BELIK, SANDRA T. DAVIDGE, WEI ZHANG, JINGYI PAN, AND JOHN J. GREER \\ Department of Pediatrics, Hospital for Sick Children, University of Toronto, Toronto, Ontario, Canada \\ M5G 1 X8 [J.B., J.P.]; and Department of Physiology, Perinatal Research Centre, University of Alberta, \\ Edmonton, Alberta, Canada T6G 2S2 [S.T.D., W.Z., J.J.G.]
}

\begin{abstract}
ABSTR
In the fetal rat, nitrofen induces congenital diaphragmatic
hernia $(\mathrm{CDH})$ and pulmonary vascular remodeling similar to
what is observed in the human condition. Airway hyperactivity is
common in infants with CDH and attributed to the ventilator-
induced airway damage. The purpose of this study was to test the
hypothesis that airway smooth muscle mechanical properties are
altered in the nitrofen-induced CDH rat model. Lungs from
nitrofen-exposed fetuses with hernias (CDH) or intact diaphragm
(nitrofen) and untreated fetuses (control) were studied on gesta-
tion d 21 . The left intrapulmonary artery and bronchi were
removed and mounted on a wire myograph, and lung expression,
content, and immunolocalization of cyclooxygenases COX-1 and
COX-2 were evaluated. Pulmonary artery muscle in the CDH
group had significantly ( $p<0.01)$ lower force generation com-
pared with control and nitrofen groups. In contrast, the same
generation bronchial smooth muscle of the CDH and nitrofen
groups developed higher force compared with control. Whereas
no differences were found in endothelium-dependent pulmonary
\end{abstract}
Persistent pulmonary hypertension is commonly associated with $\mathrm{CDH}$. Surgical correction of the diaphragmatic defect does not improve oxygenation (1), and mechanical ventilatory support with high concentrations of inspired oxygen is usually required (2). Infants with this condition surviving the immediate neonatal period have a higher prevalence of airway obstruction (3). This has been attributed to the mechanical ventilatorand oxygen-induced lung injury (4).

Nitrofen exposure during gestation results in $\mathrm{CDH}$ in the fetal rat $(5,6)$. Pulmonary vascular smooth muscle of fetuses

Received July 17, 2002; accepted October 28, 2002.

Correspondence: Jaques Belik, M.D., Division of Neonatology, Department of Pediatrics, University of Toronto, Hospital for Sick Children, Room 3886, 555 University Avenue, Toronto, Ontario, M5G 1X8, Canada; e-mail: Jaques.Belik@SickKids.ca

Supported by grants from the CIHR (J.B., S.D., J.J.G.) and March of Dimes (J.J.G.) S.D. and J.J.G. are Senior Scholars of the Alberta Heritage Foundation for Medical Research (AHFMR).

DOI: 10.1203/01.PDR.0000057986.74037.7B vascular muscle tone, the epithelium-dependent airway muscle relaxation was significantly decreased $(p<0.01)$ in the $\mathrm{CDH}$ and nitrofen groups. The lung mRNA levels of COX-1 and COX-2 were increased in the $\mathrm{CDH}$ and nitrofen groups. $\mathrm{COX}-1$ vascular and airway immunostaining, as well as COX-1 and COX-2 lung protein content, were increased in the $\mathrm{CDH}$ group. This is the first report of airway smooth muscle abnormalities in the nitrofen-induced fetal rat model of $\mathrm{CDH}$. We speculate that congenital airway muscle changes may be present in the human form of this disease. (Pediatr Res 53: 737-743, 2003)
Abbreviations
CDH, congenital diaphragmatic hernia
COX, cyclooxygenase
GAPDH, glyceraldehyde 3-phosphate dehydrogenase
ACh, acetylcholine
SNP, sodium nitroprusside

with nitrofen-induced $\mathrm{CDH}$ is known to be less responsive to pharmacologic stimulation and shows abnormal relaxation potential (7). Lung hypoplasia (8) and pulmonary airway branching abnormalities (9) are seen early in gestation in nitrofenexposed rats, suggesting that morphogenetic changes precede the diaphragmatic failure to close. However, little is known about functional changes occurring in the airway smooth muscle of this model.

The purpose of the present study was to test the hypothesis that the nitrofen-induced fetal rat model of $\mathrm{CDH}$ exhibits abnormal airway smooth muscle contraction and relaxation properties. Our initial studies confirmed the hypothesis and thus we sought to determine the factors responsible for enhanced bronchial smooth muscle contraction. Specifically, we tested the hypothesis that $\mathrm{COX}$ expression and content were increased. This line of investigation was based on evidence demonstrating that the plasma constrictor prostanoid levels are elevated in infants with CDH (10). Further, dexamethasone, a COX expression inhibitor, markedly reduces the degree of 
pulmonary vascular remodeling and lung hypoplasia (11) in the nitrofen-induced CDH model.

\section{METHODS}

The experiments were performed in accordance with institutional guidelines for animal research, and the study was approved by the Animal Welfare Committees of the University of Alberta in Edmonton and Hospital for Sick Children Research Institute in Toronto.

Administration of nitrofen. Nitrofen was obtained from the US Environmental Protection Agency and prepared as a solution of $100 \mathrm{mg} / \mathrm{mL}$ in olive oil. The timing of pregnancies was determined from the appearance of sperm plugs in the breeding cages (designated as E0). Pregnant dams on the evening of the eighth day of gestation (E8) were temporarily (approximately $10 \mathrm{~min})$ anesthetized with halothane $\left(1.25 \%\right.$ in $95 \% \mathrm{O}_{2} / 5 \%$ $\mathrm{CO}_{2}$ ) and given $100 \mathrm{mg}$ of nitrofen dissolved in $1 \mathrm{~mL}$ of olive oil via gavage tube. Control animals received a similar volume of oil on E8 and underwent similar procedures as the nitrofentreated animals.

Delivery of embryos via cesarean section and tissue preparation. Control and nitrofen-exposed fetal rats (E21) were delivered from timed-pregnant Sprague-Dawley rats anesthetized with pentobarbital sodium $(25 \mathrm{mg} / \mathrm{kg}$ i.p. $)$.

The fetal chest was opened, the presence of a diaphragmatic hernia was assessed, and the lungs were removed after perfusing them with $3 \mathrm{~mL}$ of cold-buffered saline to reduce the blood in the pulmonary circulation. On the basis of the presence or absence of a diaphragmatic hernia, the fetuses were classified into three groups: control, exposed to nitrofen but without diaphragmatic defects (nitrofen), and nitrofen-induced hernias (CDH). The lung tissue was collected, washed in saline, blotted on filter paper, weighed, frozen in liquid nitrogen, and stored at $-70^{\circ} \mathrm{C}$ for RNA extraction and Western blot analysis. The material to be used for immunohistochemistry was fixed in $4 \%$ paraformaldehyde, whereas fresh tissue was used for the vascular and bronchial smooth muscle mechanical property studies.

Organ bath studies. Ring segments of left lung intralobar bronchi and immediately adjacent pulmonary artery (average diameter, $100 \mu \mathrm{m}$; length, $2 \mathrm{~mm}$; ipsilateral to the diaphragmatic hernia) were dissected free and mounted in a wire myograph (Danish Myo Technology A/S, Aarhus, Denmark). Isometric changes were digitized and recorded online (Myodaq, Danish Myo Technology A/S). Tissues were bathed in Krebs-Henseleit buffer bubbled with $95 \% \mathrm{O}_{2} / 5 \% \mathrm{CO}_{2}$ and maintained at $37^{\circ} \mathrm{C}$. After $1 \mathrm{~h}$ of equilibration the optimal resting tension of the tissue was determined by repeated stimulation with $127 \mathrm{mM} \mathrm{KCl}$ until maximum active tension was reached. All subsequent force measurements were obtained at optimal resting tension. The pulmonary vascular muscle force generation was evaluated by stimulating with $\mathrm{KCl}$ and the thromboxane mimetic U46619. Similarly, the bronchial muscle was stimulated with $\mathrm{KCl}, \mathrm{U} 46619$, and acetylcholine (ACh). Contractile responses were normalized to the tissue crosssectional area as follows: (width $\times$ diameter) $\times 2$ and expressed as millinewtons per square millimeter. U46619 $\left(10^{-6}\right.$
$\mathrm{M})$ and $\mathrm{ACh}\left(10^{-4} \mathrm{M}\right)$ were used to precontract the pulmonary and bronchial muscle, respectively. The relaxant response to sodium nitroprusside (SNP), ACh (vascular), and substance P (bronchi) were determined. Indomethacin $\left(10^{-5} \mathrm{M}\right)$ was used to inhibit COX activity. All chemicals were dissolved in Krebs-Henseleit buffer.

The composition of the Krebs-Henseleit solution was as follows (in mM): $\mathrm{NaCl}, 115 ; \mathrm{NaHCO}_{3}, 25 ; \mathrm{NaHPO}_{4}, 1.38$; $\mathrm{KCl}, 2.51 ; \mathrm{MgSO}_{4} \cdot 7 \mathrm{H}_{2} \mathrm{O}, 2.46 ; \mathrm{CaCl}_{2}, 1.91$; and dextrose, 5.56.

RNA isolation. Total RNA was isolated from frozen tissues as described previously (12). Briefly, frozen tissue (50-100 $\mathrm{mg}$ ) was reduced to a powder in a liquid nitrogen-cooled Braun Mikro-Dismembrator Vessel (B. Braun Biotech International, Allentown, PA, U.S.A.). One milliliter of TriZol Reagent (Life Technologies, Gaithersburg, MD, U.S.A.) was added to the powder tissue and kept to room temperature to allow for complete dissociation of nucleoprotein complexes. To this suspension $0.2 \mathrm{~mL}$ of chloroform per milliliter of TriZol reagent was added. The samples were mixed vigorously, and then centrifuged at $12,000 \times g$ for $15 \mathrm{~min}$ at $4^{\circ} \mathrm{C}$. The upper aqueous phase was transferred to a fresh tube, and $0.5 \mathrm{~mL}$ of isopropyl alcohol per $1 \mathrm{~mL}$ of TriZol reagent used for initial homogenization was added. Samples were incubated at room temperature for $10 \mathrm{~min}$ and centrifuged at $12,000 \times \mathrm{g}$ for 10 $\min$ at $4{ }^{\circ} \mathrm{C}$. The RNA precipitate forms a gel-like pellet on the side and bottom of the tube. The supernatant fraction was removed, and $1 \mathrm{~mL}$ of $75 \%$ ethanol was added (per $1 \mathrm{~mL}$ TriZol reagent). Samples were then centrifuged at 7,500 $\times g$ for 5 min at $4{ }^{\circ} \mathrm{C}$, the supernatant was removed, and the RNA pellet was air-dried for $5 \mathrm{~min}$. One hundred microliters of diethylpyrocarbonate (DEPC) water was added to dissolve the pellet. The yield of RNA was quantified spectrophotometrically (U1troSpec 3000 UV/VIS spectrophotometer; Pharmacia Biotech, Cambridge, England, U.K.), and OD 260/280 ratios were determined.

COX-1 and COX-2 mRNA expression were examined using reverse-transcription PCR. The following semiquantitative reverse-transcription PCR method was used. One microgram of RNA from each sample was reverse transcribed at $42^{\circ} \mathrm{C}$ using $1 \mu \mathrm{L}$ of Superscript RNase H Reverse Transcriptase (GIBCO BRL, Gaithersburg, MD, U.S.A.) and the appropriate reaction mixture containing $2 \mu \mathrm{L}$ of $10 \times$ PCR buffer, $2 \mu \mathrm{L}$ of $10 \mathrm{mM}$ deoxynucleoside triphosphate [dNTP] stock, and $2 \mu \mathrm{L}$ of N6 random hexamer stock. The enzyme was deactivated by heating the samples to $95^{\circ} \mathrm{C}$ for $10 \mathrm{~min}$. After the reaction, $2 \mu \mathrm{L}$ of cDNA was mixed with $35 \mu \mathrm{L}$ of water (GIBCO BRL), $2 \mu \mathrm{L}$ of $2 \mathrm{mM}$ dNTP stock, $5 \mu \mathrm{L}$ of $10 \times$ PCR buffer, and $0.4 \mu \mathrm{L}$ of Platinum Taq DNA polymerase (GIBCO BRL). The upstream primer $(2 \mu \mathrm{L}$; approximately $1 \mathrm{pmol})$ and downstream primer ( $2 \mu \mathrm{L}$; approximately $1 \mathrm{pmol}$ ) under investigation were then added to each tube. The housekeeping gene for GAPDH was used as an internal control. Optimal coamplification of each primer with GAPDH was determined during preliminary trials (data not shown). The primer sequences used were as follows: GAPDH (upstream: 5'-CGG AGT CAA CGG ATT TGG TCG TAT- 3'; downstream: 5'-AGC CTT CTC CAT GGT GGT GAA GAC-3'; size: 306 bp); COX-1 (upstream: 5'- CCT TCT 
CCA ACG TGA GCT ACT A-3'; downstream: 5'- GTG GAG AAG AGC ATC AGA CC-3'; size: 486 bp); COX-2 (upstream: 5'-CCT TCC TCC TGT GGC TGA TG-3'; downstream: 5'- GGA ACA GTC GCT CGT CAT CC-3'; size: 536 $\mathrm{bp)}$.

DNA amplification was conducted under the following conditions: denaturation at $94^{\circ} \mathrm{C}$ for $1 \mathrm{~min}$, annealing at $58^{\circ} \mathrm{C}$ for $30 \mathrm{~s}$, and extension at $72^{\circ} \mathrm{C}$ for $1 \mathrm{~min}$. At the end of procedure, a final extension at $72^{\circ} \mathrm{C}$ for $5 \mathrm{~min}$ was performed. The samples were then held at $4^{\circ} \mathrm{C}$ until processing. PCR products were visualized by electrophoresis of $20 \mu \mathrm{L}$ of reaction mixture on a $2 \%$ agarose gel at $60 \mathrm{~V} / \mathrm{cm}$ in TAE buffer $(0.4 \mathrm{M}$ Tris-acetate, $0.001 \mathrm{M}$ EDTA, $\mathrm{pH}$ 8.0).

The gels were stained with ethidium bromide, and destained with distilled water. The gels were then photographed using type 55 land film (Polaroid, Cambridge, MA, U.S.A.), and analyzed by densitometry (MasterScan Interpretive Densitometer and RFLPscan; Scanalytics, Fairfax, VA, U.S.A.), as previously described (12). Integrated density values were normalized to GAPDH values to yield a semiquantitative assessment of individual transcript levels.

Immunohistochemistry. Fetal lungs were removed immediately after killing and immersed in $4 \%$ paraformaldehyde in a $0.2 \mathrm{M}$ sodium phosphate buffer $(\mathrm{pH}$ 7.4). The tissue was postfixed at $4{ }^{\circ} \mathrm{C}$ for $4-20 \mathrm{~h}$, dehydrated in a graded series of ethanols, and cleared in xylene. The fixed tissue was embedded in molten paraffin in a heating incubator at $54^{\circ} \mathrm{C}$ for $2-3 \mathrm{~d}$. After tissues were embedded, the paraffin block containing the tissue was trimmed and mounted on a rotary microtome (model 45; Lipshaw, Detroit, MI, U.S.A.) equipped with a standard knife holder and a forward-moving block. The tissue was orientated to allow for the cutting of transverse sections $(6-\mu \mathrm{m}$ thickness). Sections were mounted on gelatin-subbed microscope slides and immersed in xylene for $15 \mathrm{~min}$ to remove wax before staining. The dewaxed sections were dehydrated through a graded series of ethanols, stained with Gill's hematoxylin for $2 \mathrm{~min}$ for nuclear staining, and rinsed with distilled water. The sections were then stained for $1 \mathrm{~min}$ with eosin for cytoplasmic staining. After they were washed with distilled water, the sections were dehydrated in ethanol, equilibrated in xylene, and positioned under a glass coverslip with Entellan.

Tissues for all immunolabeling were immersed in methanol containing $0.3 \% \mathrm{H}_{2} \mathrm{O}_{2}$ for $20-45 \mathrm{~min}$, followed by incubation in 1:20 goat serum (Sigma Chemical Co., Oakville, Ontario, Canada) in PBS for $1 \mathrm{~h}$. After three 10-min PBS washes, all tissues were incubated in diluted primary antibody for $1-2$ nights at $4^{\circ} \mathrm{C}$. After three 30-min PBS washes, tissues were incubated in the appropriate secondary antibody for $1-2 \mathrm{~h}$ at room temperature. Tissues treated with antibodies were further incubated in a $1 \%$ avidin-biotinylated-peroxidase complex (ABC; kit PK-4000, Vectastain, Vector Laboratories (Canada), Inc., Burlington, Ontario, Canada) for 1-2 h. Antibody labeling was then revealed by a 3,3-diaminobenzidine tetrahydrochloride (DAB) product intensified with nickel ions $[0.1 \mathrm{M}$ Trisbuffered solution $(\mathrm{pH} 8$ ) containing $0.04 \%$ DAB with $0.04 \%$ $\mathrm{H}_{2} \mathrm{O}_{2}$ and $0.6 \%$ nickel ammonium sulfate] for 5-15 min at room temperature. This produced an intense purple-black precipitate. After being washed thoroughly, tissues were mounted and examined as above. Controls were provided by primary antibody omission or by use of an appropriate secondary antibody.

Commercially available MAb against COX-1 (Cayman, Ann Arbor, MI, U.S.A.) and COX-2 (Transduction Laboratories, Lexington, KY, U.S.A.) were used.

The lung immunohistochemistry from three animals in each group was scored in a blinded fashion assigning a value between 0 (no stain) to 5 (maximum staining). Five airways and vessels were scored from each animal.

Western blot analysis. Lung extract protein $(30-100 \mu \mathrm{g})$ was applied to $10 \%$ SDS-polyacrylamide gels and electroblotted to nitrocellulose paper. The efficiency of transfer was verified by staining the gel with Coomassie blue after the transfer. The blot was blocked overnight with $5 \%$ nonfat dry milk in TTBS (TBS, $0.1 \%$ Nonidet P40, 0.1\% Tween-20). The blots were incubated at $4^{\circ} \mathrm{C}$ overnight with 1:1000 COX-1 (Cayman Chemical) or COX-2 (Transductions Laboratories) MAb.

The secondary antibody (1:5000 antimouse IgG HRP; Amersham, Arlington Heights, IL, U.S.A.) was incubated for $1 \mathrm{~h}$ at room temperature. The cross-reactivity of the antibodies was detected by chemiluminescence using a mixture of equal volumes of enhanced luminol reagent and oxidizing reagent (ECL Western Blotting Analysis System; Amersham). The crossreactivity was quantitated by two-dimensional scanning of the autoradiograms of the blots with a high-resolution scanner (ImageMaster Analyser; Pharmacia, Peapack, NJ, U.S.A.). Purified COX-1 and COX-2 proteins (Cayman Chemical) were used as positive controls and for quantification. The data are normalized to the protein content of the lung extract.

Reagents. Unless, otherwise noted all chemicals were obtained from Sigma Chemical Co.

Data analysis. Data were evaluated by two-way ANOVA for repeat measurements and multiple comparisons were obtained by the Newman-Keuls test when appropriate (NCSS, Kaysville, UT, U.S.A.). Statistical significance was accepted if $p<0.05$. Data are presented as mean $\pm \mathrm{SD}$.

\section{RESULTS}

The pulmonary artery smooth muscle force generation after stimulation with $\mathrm{KCl}(85$ and $127 \mathrm{mM}$ ) and U46619 (thromboxane mimetic) in the $\mathrm{CDH}$ group were significantly decreased $(p<0.01)$ as compared with the control and nitrofen groups (Fig. 1). There were no significant differences among the three groups in the endothelium-dependent relaxation in response to ACh. However, the overall relaxation to $\mathrm{ACh}$ was minimal $(<25 \%)$ for all the groups. After addition of the nitric oxide donor SNP, significant relaxation was observed in all groups with a slight, but greater, response in the $\mathrm{CDH}$ group at $10^{-4} \mathrm{M}$ (Fig. 1).

After KCl-induced stimulation, the bronchial smooth muscle from nitrofen and $\mathrm{CDH}$ groups showed a significantly greater force $(p<0.01)$ compared with the control group (Fig. 2). In response to U46619 stimulation, the nitrofen-treated bronchial smooth muscle force was significantly greater than that of $\mathrm{CDH}$ and control groups $(p<0.01$; Fig. 2$)$. No significant 

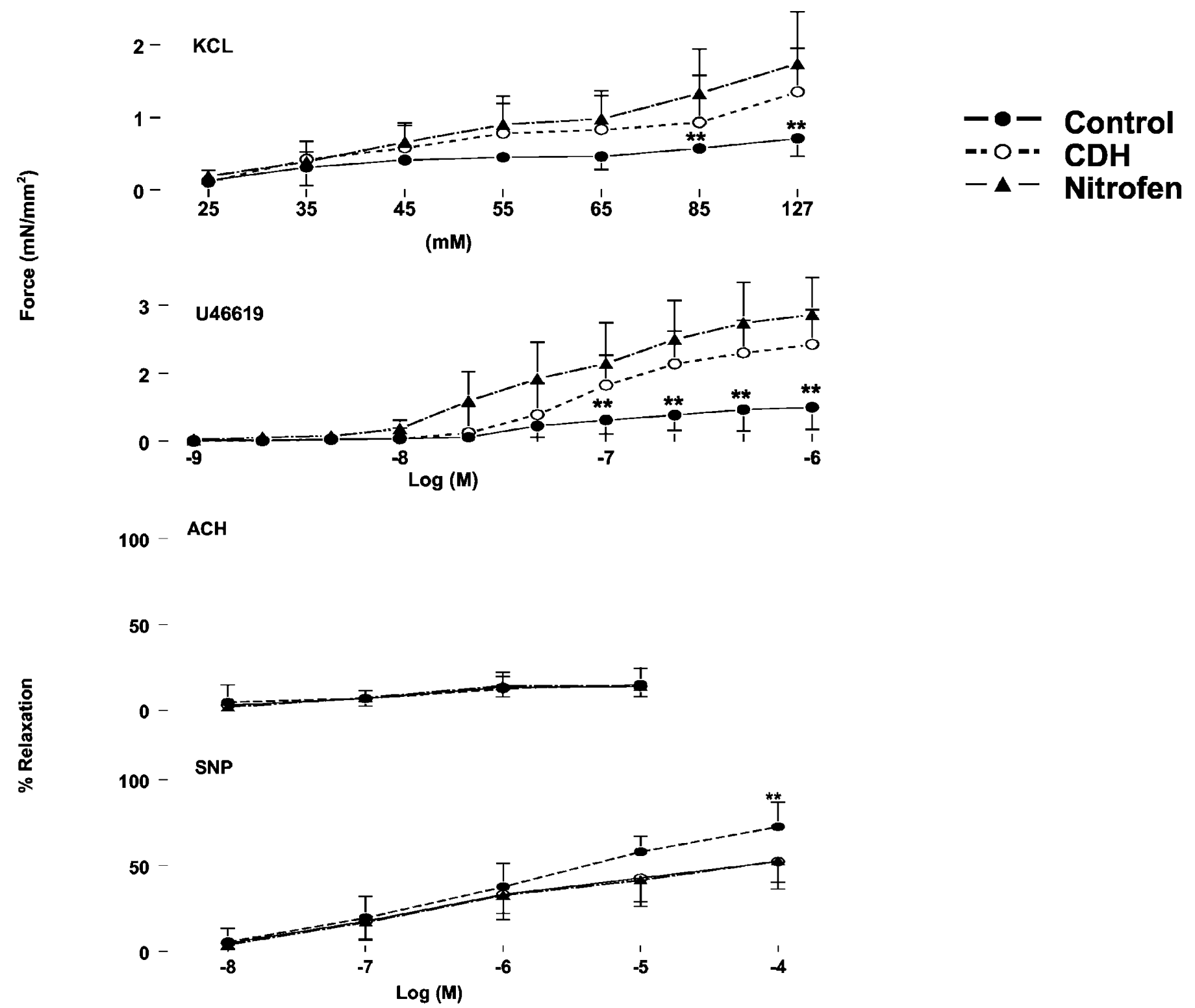

Figure 1. Pulmonary arterial smooth muscle force generation ( $\mathrm{KCl}$ and $\mathrm{U} 46619)$ and relaxation (Ach, SNP) for control $(n=19)$, nitrofen $(n=5)$, and $\mathrm{CDH}$ $(n=7)$ animals. For the relaxation studies, the vessels were preconstricted with U46619 $\left(10^{-6} \mathrm{M}\right)$. Significant difference in the U46619 dose-response curves between $\mathrm{CDH}$ and the other two groups was observed ( $p<0.01$; ANOVA). ${ }^{* *} p<0.01$ vs control and nitrofen groups.

group differences in the ACh dose-response curves were observed in the absence or presence of indomethacin (Fig. 2).

Whereas no significant group difference in dose-response relationship to SNP was observed, the substance P-induced relaxation was significantly decreased $(p<0.01)$ in the nitrofen and CDH groups (Fig. 3). Indomethacin significantly ( $p<$ 0.01 ) reduced the magnitude of substance $\mathrm{P}$-induced bronchial smooth muscle relaxation in control to the level of the $\mathrm{CDH}$ and nitrofen group results (Fig. 3).

The lung COX-1 mRNA level increased in the CDH group compared with control ( $p<0.05$; Fig. 4$)$. The lung COX-2 mRNA levels were significantly increased in the nitrofen group $(p<0.05)$, whereas the $\mathrm{CDH}$ group exhibited higher, but not statistically significant, levels compared with control (Fig. 4).

Western blot analysis of the lung samples showed a significant increase in COX-1 and COX-2 protein in the CDH lungs.
The COX-1 lung protein content increased $(p<0.05)$ from 4.5 $\pm 1.4 \mathrm{ng} / \mathrm{g}$ protein in the control $(n=4)$ to $12.9 \pm 7.7 \mathrm{ng} / \mathrm{g}$ protein in the CDH group $(n=4)$. The COX-2 lung protein content was $58.6 \pm 29.4 \mu \mathrm{g} / \mathrm{g}$ protein in the $\mathrm{CDH}(n=4)$, significantly higher $(p<0.05)$ than the control group $(17.0 \pm$ $10.1 \mu \mathrm{g} / \mathrm{g}$ protein; $n=4)$.

Figure 5 illustrates the lung immunohistochemistry for the COX proteins. Specific staining for COX-1 protein is seen around the vessels and airways of the control lungs. In the $\mathrm{CDH}$ lungs, the COX-1 protein abundance is more evident around the airway, compared with the control group. Specific staining for COX-2 protein was only evident in the airways. Table 1 shows the scoring values for the lung COX-1 and COX-2 immunostaining. The vascular and airway COX-1 scores were significantly higher in the $\mathrm{CDH}$ group, whereas no significant change was observed for the COX-2 scores. 


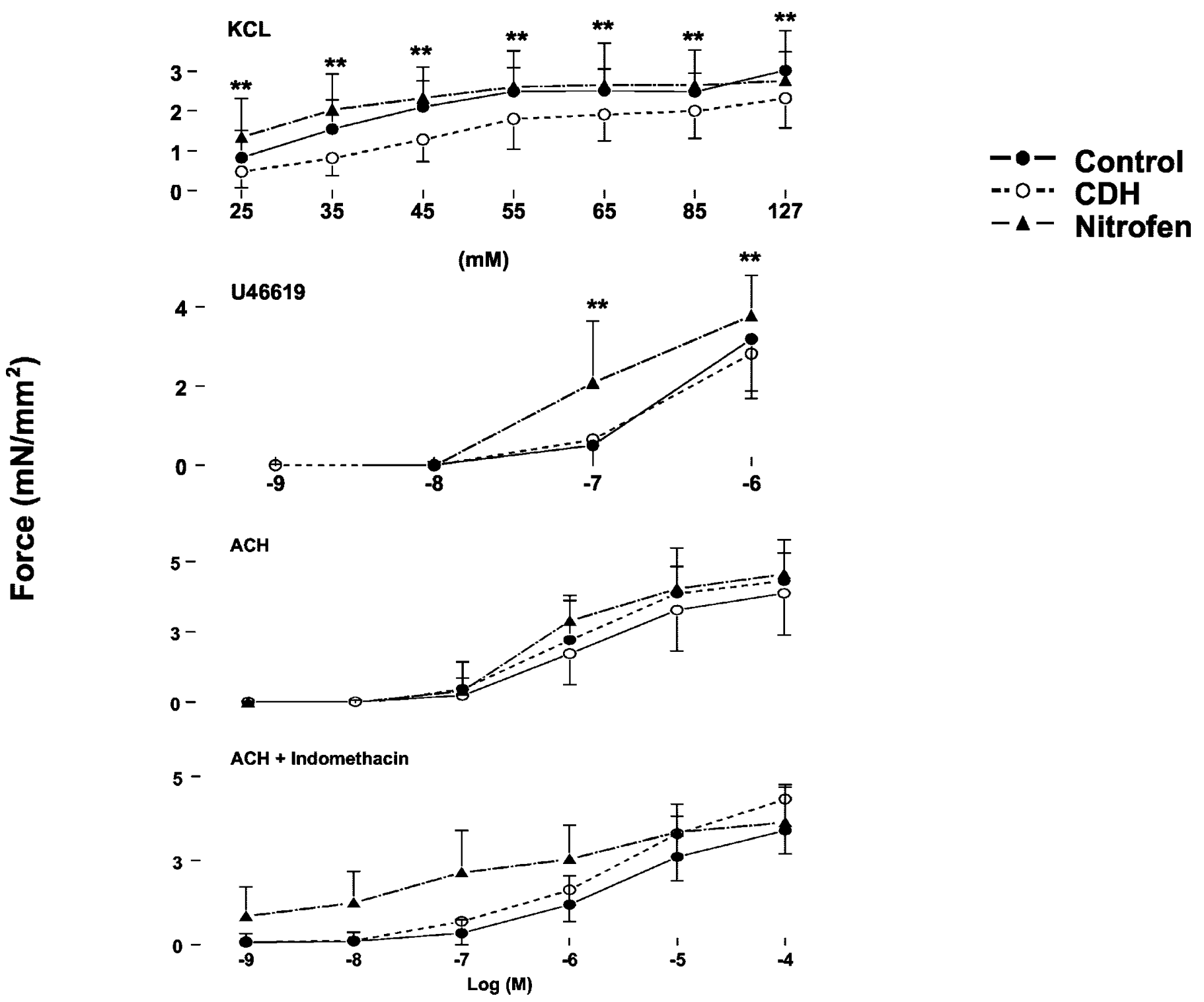

Figure 2. Airway smooth muscle dose-response curves to $\mathrm{KCl}$, U46619, and $\mathrm{ACh}$ (without and with indomethacin $\left.10^{-5} \mathrm{M}\right)$. The $\mathrm{CDH}(n=4)$ and nitrofen $(n=7)$ airway muscle $\mathrm{KCl}$-induced force was significantly greater than the control $(n=8)$ group $\left(p<0.01\right.$; ANOVA). ${ }^{* *} p<0.01 v s$ control group.

\section{DISCUSSION}

A single oral dose of nitrofen on $\mathrm{d} 8$ of pregnancy results in fetal diaphragmatic hernia in rats (5). Similar to the human neonatal condition (13), the diaphragmatic defect is accompanied by lung hypoplasia and histologic evidence of pulmonary vascular remodeling. As shown in this study, significant changes in vascular and airway smooth muscle mechanical properties are associated with $\mathrm{CDH}$. The pulmonary artery smooth muscle develops less force than the control group counterpart. In contrast, an increased airway smooth muscle force generation after stimulation with $\mathrm{KCl}$ and thromboxane mimetic was observed in the $\mathrm{CDH}$ group. The bronchial smooth muscle relaxation potential was similar for all groups after exposure to a nitric oxide donor, but significantly reduced in response to substance $\mathrm{P}$. These changes were associated with increased lung COX mRNA levels and protein abundance in the $\mathrm{CDH}$ group.
The observed lower pulmonary vascular smooth muscle isometric force generation in the $\mathrm{CDH}$ group contrasts with the available data obtained in pressurized vessels. Au-Fliegner M. et al. (14) reported that the pulmonary arteries of $\mathrm{CDH}$ fetuses constricted to a similar degree as control when stimulated with $\mathrm{KCl}$, phenylephrine, angiotensin II, serotonin, and U46619. In response to endothelin-1, the $\mathrm{CDH}$ pulmonary arterial vessels constricted to a greater extent than control vessels (15). However, Newell et al. (16) showed that the hypoxia-induced vasoconstriction is blunted in the $\mathrm{CDH}$ pulmonary arteries. Oxygen-induced vasodilation has been shown to be impaired in the pulmonary arteries of fetal rats with $\mathrm{CDH}$ (7), suggesting that the relaxation potential of these vessels is reduced. In the present study the pulmonary arterial relaxation response to $\mathrm{ACh}$ and SNP was not impaired in the $\mathrm{CDH}$ group. The apparently discrepant data relative to the pulmonary arterial muscle potential for contraction and relaxation likely reflect 


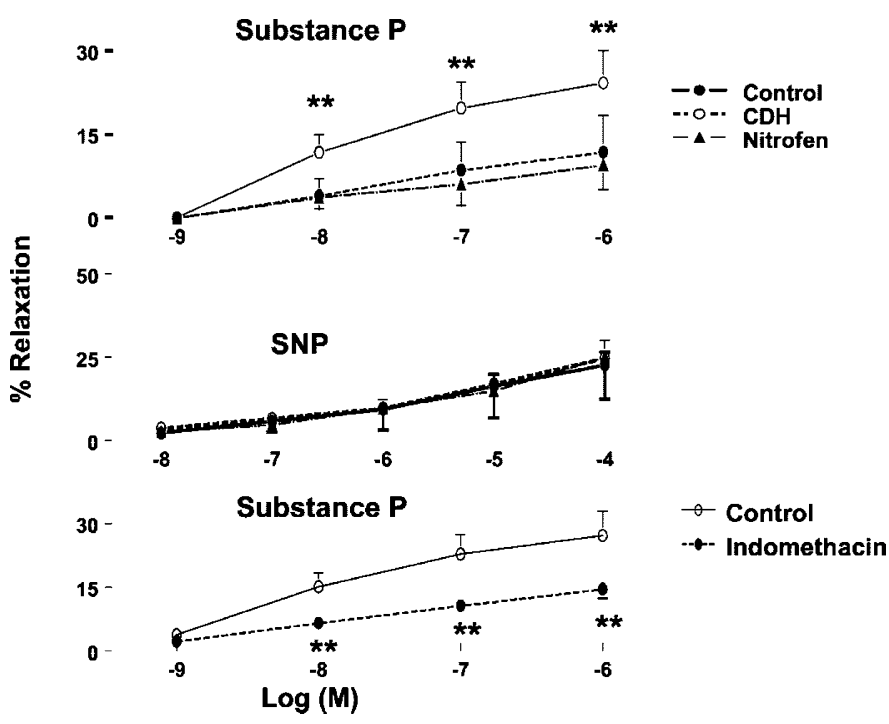

Figure 3. Substance P and SNP induced relaxation of bronchial muscle precontracted with ACh $\left(10^{-4} \mathrm{M}\right)$ from control $(n=24)$, nitrofen $(n=7)$ and $\mathrm{CDH}(n=8)$ animals. Significant differences $(p<0.01$; ANOVA $)$ in the substance $\mathrm{P}$ dose-response curves were observed in the $\mathrm{CDH}$ and nitrofen groups, as compared with the control group. Indomethacin significantly decreased the magnitude of the substance $\mathrm{P}$-induced relaxation $(p<0.01$ ANOVA). ${ }^{* *} p<0.01 v s$ control and nitrofen groups.

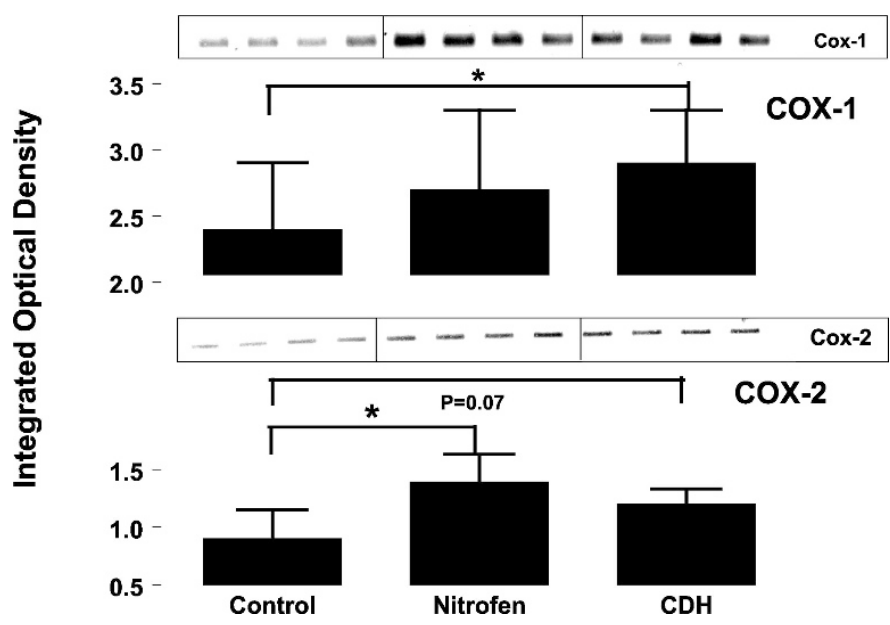

Figure 4. Lung COX-1 and COX-2 mRNA levels for control, nitrofen, and $\mathrm{CDH}$ groups ( $n=5$ in each group) expressed in arbitrary units. ${ }^{*} p<0.05 v \mathrm{~s}$ control group.

methodological differences. In another fetal model of pulmonary hypertension, we have previously shown that the pulmonary arterial smooth muscle has a lower potential for contraction and abnormal relaxation properties (17).

In contrast to the changes in the pulmonary vasculature, the bronchial smooth muscle of the nitrofen-exposed (with and without $\mathrm{CDH}$ ) showed a greater potential for contraction and lesser ability to relax in response to an epithelial-derived factor (substance P). These changes in the muscle mechanical properties were associated with immunohistochemical evidence of increased airway expression and total lung content of COX-1. This is in keeping with the increased levels of constrictor prostaglandins documented in human infants with $\mathrm{CDH}(10$, $18,19)$.
COX-1
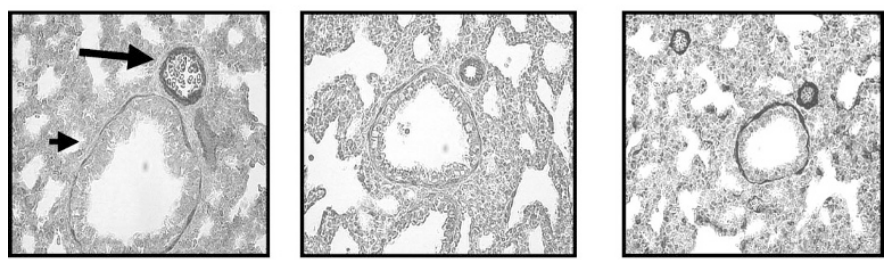

coX-2
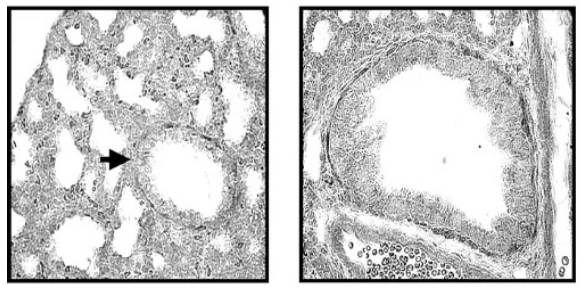

NITROFEN

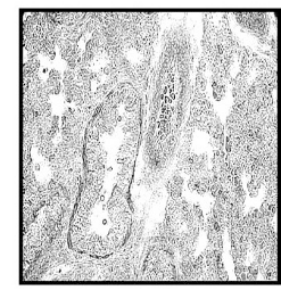

CDH

Figure 5. Representative lung immunohistochemistry for COX-1 and COX-2. The control, nitrofen, and $\mathrm{CDH}$ lung slices were mounted on the same slide for processing. Notice the immunostaining around a pulmonary vessel (large arrow) and an airway (small arrow; magnification, $\times 400)$.

Table 1. Lung immunohistochemistry scoring for $C O X-1$ and $\mathrm{COX}-2$ *

\begin{tabular}{cccc}
\hline & Control & Nitrofen & $\mathrm{CDH}$ \\
\hline COX-1 & & & \\
Vascular & $2.1 \pm 0.9$ & $1.1 \pm 1.0$ & $3.3 \pm 0.5 \dagger$ \\
Airway & $2.1 \pm 0.7$ & $1.5 \pm 1.0$ & $2.7 \pm 0.5 \dagger$ \\
COX-2 & & & \\
Vascular & $0 \pm 0$ & $0 \pm 0$ & $0 \pm 0$ \\
Airway & $1.3 \pm 0.5$ & $1.5 \pm 0.5$ & $1.5 \pm 0.5$ \\
\hline
\end{tabular}

* Values are mean $\pm \mathrm{SD}$

** $P<0.01$ compared with control and nitrofen groups by ANOVA.

The distinct relaxant response to substance $\mathrm{P}$ is suggestive of altered airway epithelial prostaglandin synthesis or expression of their receptors. In mice, the substance $\mathrm{P}$-induced relaxant response has been shown to involve prostaglandin $\mathrm{E}_{2}$ release from airway epithelial cells, and is abnormal in the $\mathrm{EP}_{2}$ receptor knockout mouse $(20,21)$. Diminished prostaglandin $\mathrm{E}_{2}$ release is responsible for increased canine tracheal muscle force generation related to epithelial removal or blockade with indomethacin (22). Using mice with a gene-targeted deletion of the $\mathrm{EP}_{2}$ receptor, the substance $\mathrm{P}$ relaxation of tracheal smooth muscle is significantly reduced (20). In the present study, we documented a significantly reduced smooth muscle relaxation to substance $\mathrm{P}$ in the $\mathrm{CDH}$ and nitrofen groups. The magnitude of the relaxation was on average $50 \%$ of the control group response and similar to the values obtained after indomethacin blockade.

The observed airway changes in the nitrofen group raises the issue of whether they reflect toxicity, or are related to the pathogenesis of $\mathrm{CDH}$. Others strongly argued against a toxic effect of nitrofen on the changes observed in the pulmonary vascular contractile or dilator potential $(7,15,23)$. We concur with their view. However, the airway muscle findings that we observed in the nitrofen group suggest that lung parenchymal changes may occur in parallel with the embryogenesis of the diaphragmatic defect, and have a common origin. Whereas pulmonary hypertension and lung hypoplasia occur after sur- 
gically induced diaphragmatic defects in fetal sheep (24-27), in the rat model of $\mathrm{CDH}$, lung hypoplasia is not entirely explained by the presence of bowel in the chest cavity $(8,28)$.

Interestingly, nitrofen and other teratogens known to induce $\mathrm{CDH}$ in rodents suppress the activation of the retinoid response element by inhibiting retinal dehydrogenase $(29,30)$. Disruption of the retinoid signaling pathway could contribute to the lung parenchymal changes in the $\mathrm{CDH}$ rat model. Furthermore, retinoic acid has been shown to modulate nitric oxide production in vascular smooth muscle (31) and integrins (32) in the rat. Retinoic acid is also involved in ductus arteriosus smooth muscle differentiation in the fetus (33). Thus, the pathogenesis of $\mathrm{CDH}$ in humans may also result from a factor(s) capable of disrupting the embryogenesis of the diaphragm, as well as inducing lung parenchymal changes unrelated to the presence of abdominal contents in the chest.

\section{CONCLUSIONS}

In summary, the present data indicate that nitrofen-induced $\mathrm{CDH}$ is associated with significant changes in airway muscle mechanical properties, as well as expression and content of lung $\mathrm{COX}$ at birth. Given the present findings in this animal model, further investigation on the airway smooth muscle properties in infants with $\mathrm{CDH}$ is warranted based on the higher prevalence of airway hyperresponsiveness in this condition.

\section{REFERENCES}

1. Hazebroek FW, Tibboel D, Bos AP, Pattenier AW, Madern GC, Bergmeijer JH, Molenaar JC 1988 Congenital diaphragmatic hernia: impact of preoperative stabilization. A prospective pilot study in 13 patients. J Pediatr Surg 23:1139-1146

2. Walsh MC, Stork EK 2001 Persistent pulmonary hypertension of the newborn. Rational therapy based on pathophysiology. Clin Perinatol 28:609-627

3. Muratore CS, Kharasch V, Lund DP, Sheils C, Friedman S, Brown C, Utter S, Jaksic T, Wilson JM 2001 Pulmonary morbidity in 100 survivors of congenital diaphragmatic hernia monitored in a multidisciplinary clinic. J Pediatr Surg 36:133-140

4. Broughton AR, Thibeault DW, Mabry SM, Truog WE 1998 Airway muscle in infants with congenital diaphragmatic hernia: response to treatment. J Pediatr Surg 33:14711475

5. Greer JJ, Allan DW, Babiuk RP, Lemke RP 2000 Recent advances in understanding the pathogenesis of nitrofen-induced congenital diaphragmatic hernia. Pediatr Pulmonol 29:394-399

6. Greer JJ, Cote D, Allan DW, Zhang W, Babiuk RP, Ly L, Lemke RP, Bagnall K 2000 Structure of the primordial diaphragm and defects associated with nitrofen-induced CDH. J Appl Physiol 89:2123-2129

7. Coppola CP, Gosche JR 2001 Oxygen-induced vasodilation is blunted in pulmonary arterioles from fetal rats with nitrofen-induced congenital diaphragmatic hernia. J Pediatr Surg 36:593-597

8. Guilbert TW, Gebb SA, Shannon JM 2000 Lung hypoplasia in the nitrofen model of congenital diaphragmatic hernia occurs early in development. Am J Physiol Lung Cell Mol Physiol 279:L1159-L1171

9. Keijzer R, Liu J, Deimling J, Tibboel D, Post M 2000 Dual-hit hypothesis explains pulmonary hypoplasia in the nitrofen model of congenital diaphragmatic hernia. Am J Pathol 156:1299-1306
10. Nakayama DK, Motoyama EK, Evans R, Hannakan C 1992 Relation between arterial hypoxemia and plasma eicosanoids in neonates with congenital diaphragmatic hernia. J Surg Res 53:615-620

11. Oue T, Shima H, Guarino N, Puri P 2000 Antenatal dexamethasone administration increases fetal lung DNA synthesis and RNA and protein content in nitrofen-induced congenital diaphragmatic hernia in rats. Pediatr Res 48:789-793

12. Belik J, Karpinka B, Hart DA 2000 Pulmonary and systemic vascular tissue collagen, growth factor, and cytokine gene expression in the rabbit. Can J Physiol Pharmacol 78:400-406

13. Weinberger B, Weiss K, Heck DE, Laskin DL, Laskin JD 2001 Pharmacologic therapy of persistent pulmonary hypertension of the newborn. Pharmacol Ther 89:67-79

14. Au-Fliegner M, Salami S, Gosche JR 1998 Pulmonary arterioles from rats with congenital diaphragmatic hernias are hypoplastic but not hyperresponsive. J Pediatr Surg 33:1366-1370

15. Coppola CP, Au-Fliegner M, Gosche JR 1998 Endothelin-1 pulmonary vasoconstriction in rats with diaphragmatic hernia. J Surg Res 76:74-78

16. Newell MA, Au-Fliegner M, Coppola CP, Gosche JR 1998 Hypoxic pulmonary vasoconstriction is impaired in rats with nitrofen-induced congenital diaphragmatic hernia. J Pediatr Surg 33:1358-1362

17. Belik J, Halayko AJ, Rao K, Stephens NL 1993 Fetal ductus arteriosus ligation: pulmonary vascular smooth muscle biochemical and mechanical changes. Circ Res 72:588-596

18. Bos AP, Tibboel D, Hazebroek FW, Stijnen T, Molenaar JC 1990 Congenital diaphragmatic hernia: impact of prostanoids in the perioperative period. Arch Dis Child 65:994-995

19. Ford WD, James MJ, Walsh JA 1984 Congenital diaphragmatic hernia: association between pulmonary vascular resistance and plasma thromboxane concentrations. Arch Dis Child 59:143-146

20. Fortner CN, Breyer RM, Paul RJ $2001 \mathrm{EP}_{2}$ receptors mediate airway relaxation to substance P, ATP, and $\mathrm{PGE}_{2}$. Am J Physiol Lung Cell Mol Physiol 281:L469-L474

21. Kao J, Fortner CN, Liu LH, Shull GE, Paul RJ 1999 Ablation of the SERCA3 gene alters epithelium-dependent relaxation in mouse tracheal smooth muscle. Am J Physiol 277:L264-L270

22. McGrogan I, Daniel EE 1996 Release and actions of inhibitory prostaglandins from canine tracheal epithelium. Can J Physiol Pharmacol 74:1055-1060

23. Tenbrinck R, Gaillard JL, Tibboel D, Kluth D, Lachmann B, Molenaar JC 1992 Pulmonary vascular abnormalities in experimentally induced congenital diaphragmatic hernia in rats. J Pediatr Surg 27:862-865

24. Hill AC, Adzick NS, Stevens MB, Mori H, Husseini W, Heymann MA 1994 Fetal lamb pulmonary hypoplasia: pulmonary vascular and myocardial abnormalities. Ann Thorac Surg 57:946-951

25. Lipsett J, Cool JC, Runciman SC, Ford WD, Parsons DW, Kennedy JD, Martin AJ 2000 Effect of immediate versus slow intrauterine reduction of congenital diaphragmatic hernia on lung development in the sheep: a morphometric analysis of term pulmonary structure and maturity. Pediatr Pulmonol 30:228-240

26. Irish MS, Glick PL, Russell J, Kapur P, Bambini DA, Holm BA, Steinhorn RH 1998 Contractile properties of intralobar pulmonary arteries and veins in the fetal lamb model of congenital diaphragmatic hernia. J Pediatr Surg 33:921-928

27. O'Toole SJ, Karamanoukian HL, Irish MS, Sharma A, Holm BA, Glick PL 1997 Tracheal ligation: the dark side of in utero congenital diaphragmatic hernia treatment. J Pediatr Surg 32:407-410

28. Alfonso LF, Arnaiz A, Alvarez FJ, Qi B, Diez-Pardo JA, Vals-i-Soler A, Tovar JA 1996 Lung hypoplasia and surfactant system immaturity induced in the fetal rat by prenatal exposure to nitrofen. Biol Neonate 69:94-100

29. Chen J, MacGowan A, Ward S, Bavik C, Greer J 2002 Activation of the retinoid response element is inhibited in an animal model of congenital diaphragmatic hernia. Biol Neonate (in press)

30. Greer JJ, Mey J, Babiuk RP, Lugston R 2002 Retinal dehydrogenase is inhibited by compounds that induce congenital diaphragmatic hernia. Pediatr Res 51:333A(abstr)

31. Sirsjo A, Gidlof AC, Olsson A, Torma H, Ares M, Kleinert H, Forstermann U, Hansson GK 2000 Retinoic acid inhibits nitric oxide synthase-2 expression through the retinoic acid receptor- $\alpha$. Biochem Biophys Res Commun 270:846-851

32. Medhora MM 2000 Retinoic acid upregulates $\beta(1)$-integrin in vascular smooth muscle cells and alters adhesion to fibronectin. Am J Physiol Heart Circ Physiol 279:H382-H387

33. Wu GR, Jing S, Momma K, Nakanishi T 2001 The effect of vitamin A on contraction of the ductus arteriosus in fetal rat. Pediatr Res 49:747-754 